\author{
Ks. Piotr Jamiol MS
}

\title{
KS. MICHAE KOLBUCH MS (1889-1957) - APOSTOŁ MATKI BOŻEJ Z LA SALETTE
}

\begin{abstract}
W S T E P
Miłość Boga i bliźniego jest osią życia chrześcijańskiego, wokół której koncentrują się laska i cnota, heroizm i świętość. To one ukierunkowały posłannictwo życiowe świętych i błogosławionych wszystkich czasów i pokoleń, ogrywając także ogromną rolę w działalności zmarłego 13 grudnia 1957 r. ks. Michała Kolbucha. Chociaż w roku 2007 minęto 50 lat, kiedy odszedl do wieczności, to jednak pamięć o nim jest wciąż żywa, przede wszystkim wśród saletynów. Ks. Kolbuch był pierwszym polskim saletynem, a także pierwszym prowincjałem polskiej prowincji Matki Bożej Królowej Polski oraz dokonał licznych dzieł saletyńskich. On również dal początek nowej prowincji pod wezwaniem Matki Bożej Królowej Pokoju w Olivet, w stanie Illinois (USA), która funkcjonowała do roku 2000, a później została włączona w prowincję Matki Ameryki.

Jako saletyn i syn narodu polskiego, a przede wszystkim misjonarz, kierował się zdecydowanie, na każdym kroku, wiara, przebaczeniem, ewangelicznym prawem miłości i tymi wartościami żył. Nie ograniczał się jedynie do pracy nad własnym uświęceniem czy rozwojem zgromadzenia, lecz zabiegał także o rozwój kultu Matki Bożej Saletyńskiej w Polsce, w Stanach Zjednoczonych, w Argentynie i w Rzymie oraz dbał o odrodzenie duchowe społeczeństwa w trudnych czasach okresu międzywojennego i powojennego. Podejmowane przez niego w tym czasie akcje duszpasterskie, zwłaszcza dzieło ewangelizacji oraz jego nieprzeciętna osobowość - to racje, które uzasadniają nasze zainteresowanie tą postacią.

$Z$ uwagi na zasługi położone także na polu charytatywnym na terenie ziemi włoskiej na rzecz byłych żołnierzy polskich z drugiej wojny światowej, ich rodzin oraz uchodźców, obowiązkiem naszym jest przypomnieć sylwetkę ks. Michała Kolbucha. Niech ten krótki artykuł będzie skromnym hołdem i wyrazem czci dla Jego Postaci. Oby przykład Jego życia pobudzał nas wszystkich, którzy mamy wspólne z nim powołanie saletyńskie do większej gorliwości, umiłowania życia w pokorze, prostocie
\end{abstract}


i uwielbieniu, byśmy według Bożego planu układali swoje życie doczesne i doszli do pełni szczęścia i Nieśmiertelności.

Mam nadzieję, że w ten sposób przedstawiona biografia ks. Michała Kolbucha przybliży wszystkim Czytelnikom postać tego niezwykłego kapłana-misjonarza, żyjacego w ciągłym zjednoczeniu z Bogiem i pałającego żarliwością apostolską. Główną bazę źródłową dla niniejszego życiorysu stanowiły materiały archiwalne, dostępne w saletyńskich archiwach.

\section{MŁODOŚĆ I FORMACJA ZAKONNA}

Ks. Michał Kolbuch, syn Jana i Marii z domu Kapij, urodził się i został ochrzczony 14 listopada 1889 r. w miasteczku Busk-Wolany w archidiecezji lwowskiej ${ }^{1}$. Miejscowość ta wówczas należała do Galicji, którą włączono do Monarchii Austrowęgierskiej. Później po odzyskaniu przez Polskę niepodległości w 1918 r., Busk należał do powiatu Kamionka Stumiłowa i do województwa lwowskiego. W latach 1945-1991 Busk należał do ZSRR. Od roku 1991 znajduje się w diecezji lwowskiej na terenie Ukrainy. W 1992 r. posługę w parafii katolickiej pod wezwaniem św. Stanisława, biskupa i męczennika w Busku objęli Misjonarze Matki Bożej z La Salette, którzy pracują tam z wielkim oddaniem i zaangażowaniem szerząc kult Maryi z La Salette.

Michał Kolbuch w rodzinnej parafii przystapił 15 czerwca 1902 r. do pierwszej Komunii św. ${ }^{2}$, a w dniu 2 września 1903 r. w czasie wizytacji kanonicznej parafii, otrzymał sakrament bierzmowania z rąk abpa Józefa Bilczewskiego, metropolity lwowskiego, przyjmując imię Franciszek ${ }^{3}$. Pochodził z rodziny niezamożnej. Świadczy o tym korespondencja miedzy Zakładem Misjonarzy Matki Bożej z La Salette w Tournai (Belgia) a rodzicami Michała, kandydata do Małego Seminarium. Z korespondencji tej wynika, że w pierwszym roku z powodu wydatków na podróż i wyprawę, syn ich był zwolniony od wszelkich opłat, a w następnych 5-6 latach dzielących go od wyższego seminarium, rodzice jego płacili 80 koron zamiast 100 na rok za naukę syna $i$ utrzymanie. W tym bowiem czasie liczyło się na złote reńskie i korony".

Młody Michał zaczął uczęszczać w wieku 9 lat do męskiej Szkoły Ludowej 6-klasowej w Busku (od dnia 1 września 1898 r. do 30 kwietnia 1904 r. ${ }^{5}$ ). Według „Zawiadomienia Szkolnego" z szóstej klasy obejmującego trzy trymestry roku szkolnego 1903/1904, Michał nie uczył się dobrze ${ }^{6}$. Na świadectwie z klasy szóstej miał oceny dostateczne i niedostateczne, a mało dobrych i bardzo dobrych, z wyjątkiem ocen $z$ religii, czytania, śpiewu i ćwiczeń cielesnych ${ }^{7}$. Pilność mała lub dość dobra, obyczaje do-

${ }^{1}$ Archiwum Prowincjalne Misjonarzy Matki Bożej z La Salette w Krakowie (Dalej cyt. APSK), Karta personalna ks. Michata Kolbucha; Archiwum Zgromadzenia Misjonarzy Matki Bożej z La Salette w Rzymie (AZSR), Fiche du personnel Michel Kobuch; Notice biographique Michel Kolbuch; Notice necrologique du R.P. Michel Kolbuch, Rome 7.01.1958, s. 1.

${ }^{2}$ Tamże.

${ }^{3}$ Tamże.

${ }^{4}$ Tamże.

${ }^{5}$ AZSR, Zawiadomienie szkolne klasy szóstej Michata Kolbucha.

${ }^{6}$ Tamże.

${ }^{7}$ Tamże. 
bre, postęp ogólny niedostateczny ${ }^{8}$. W uwagach ogólnych znajduje się adnotacja poczyniona przez nauczyciela klasy: "Bardzo często szkołę opuszcza i zbyt mało się uczy". W rubryce „liczba opuszczonych godzin naukowych” czytamy: „od 1 września do 15 listopada 1903 r. usprawiedliwionych 35 godzin, od 16 listopada do 31 stycznia $1904 \mathrm{r}$. usprawiedliwionych 90 godzin, nieusprawiedliwionych 20 . W okresie od 1 lutego do 15 kwietnia 1904 r. usprawiedliwionych 75 godzin" ". Ś wiadectwo zostało wydane dnia 1 maja 1904 r., z uwagą: „Ponieważ uczeń ten udaje się do zakładu salezjanów w Tournai w Belgii - wydaje się niniejsze świadectwo" ". Fakt pomylenia nazwy zgromadzenia świadczy o tym, że saletyni nie byli znani kierownikowi szkoły, gdyż pomieszal ich z salezjanami, co i dziś jeszcze niektórzy tak czynią.

Trudno jest dziś ustalić, co było przyczyną absencji Michała w szkole: brak zdrowia? Pilne zajęcia $w$ pracach polowych czy przy gospodarstwie rodziców? A może uleganie duchowi czasu? Bo dawniej rodzice nie przykładali większej wagi do szkoły i posyłali dzieci na naukę tylko wtedy, gdy nie było pilnych prac polowych. Przypominam sobie jak opowiadał mój ojciec o swoim ojcu, który był dobrym stolarzem i cieśla oraz samoukiem w znajomości sztuki pisania i czytania, że jego ojciec chełpił się tym, iż zapłacił dwa reńskie kary, ale i tak syna, czyli mojego dziadka, nie posłał do szkoły ludowej. Ewentualnie mogły by jeszcze inne przyczyny, które zdecydowanie utrudniły udział w zajęciach szkoinych Michała?

Michał musiał być zdolnym i rozgarniętym chłopcem, skoro pomimo złych ocen na świadectwie z szóstej klasy, miejscowy wikariusz ks. Oswald Loretan, saletyn, zwerbował go do Małego Seminarium Misjonarzy Matki Bożej z La Salette i wysłał do Belgii $^{12}$. Ks. Loretan zwerbował go w ciagu roku szkolnego, w trzecim trymestrze, nie pozwalając mu nawet dokończyć szóstej klasy w Busku. Rodzice Michała wyrazili na to zgodę pismem danym w Busku na Wolanach 22 kwietnia 1904 r. Szybko wystawiono paszport dla chłopca, który nosi datę 28 kwietnia 1904 r. oczywiście był to paszport austriacki, w języku niemieckim i polskim. Zaczynał się uroczystą formułą: W imieniu Najjaśniejszego Franciszka Józefa I, Cesarza Austrii, Króla Czech itd. i Apostolskiego Króla Węgier. Wydany został w Kamionce Strumiłowej, z ważnością na trzy lata. Warto podkreślić, że było to pierwsze powołanie Misjonarzy Matki Bożej z La Salette z polskiej ziemi, jeszcze przed ich otwarciem pierwszego domu zakonnego w Puźnikach (archidiecezja lwowska), który erygowano w dniu 17 sierpnia w $1905 \mathrm{r}^{13}$

W dniu 8 maja 1904 r. Michał Kolbuch przyjechał pociagiem do Tournai (Belgia) wraz z ks. Oswaldem Loretan i z kandydatami do Zgromadzenia Misjonarzy Matki Bożej z La Salette (Hipolit Dąbrowski, Franciszek Węgier i Jan Krzyworączka) ${ }^{14}$. Wszy-

\footnotetext{
${ }^{8}$ Tamże.

${ }^{9}$ Tamże.

${ }^{10}$ Tamize.

"Tamże.

${ }^{12}$ Tamże.

${ }^{13}$ AZSR, syg. G 10-II, Ksiega uchwat rady generalnej, t. 2:1894-1908, s. 233.

${ }^{14}$ Jan Krzyworączka byl kandydatem na brata zakonnego, który rozpoczął swoją formację zakonną w Tournai (Belgia). Po ukończeniu postulatu i krótkim pobycie w nowicjacie wystąpił 21 grudnia $1904 \mathrm{r}$. i powrócił do Polski. Przyczyną wystąpienia były trudności związane z nauką języka francuskiego oraz
} 
scy kandydaci pochodzili z archidiecezji lwowskiej. W dniu 19 sierpnia 1904 r. przyjechał do Tournai ks. Salomon Schalbetter w charakterze nauczyciela języka francuskiego dla małoseminarzystów pochodzacych z Polski. Wraz z nim przyjechali chłopcy $z$ archidiecezji lwowskiej jako kandydaci do Małego Seminarium: Karol Litowski, Jan Mitelski i Michał Sikora. Ks. Schalbetter od 16 września 1902 r. przebywał na terenie ziem polskich, gdzie nauczył się języka polskiego, a w Tournai przez cały rok był nauczycielem języka francuskiego i niemieckiego dla małoseminarzystów polskiego pochodzenia ${ }^{15}$.

Michał w latach 1904-1911 uczył się w Małym Seminarium saletynów w Tournai, gdzie ukończył szkołę średnią. Ks. Michał Kolbuch po latach często wracał pamięcią do czasów małoseminaryjnych w Tournai, opowiadając o tym dębowieckim małoseminarzystom w czasie konferencji. Mówił im o tym jak został zwerbowany do Małego Seminarium w Tournai w Belgi; jak był niegrzeczny w pociagu w drodze do Tournai do tego stopnia, że chciano go zawrócić z drogi. Wspominal również, iż wszyscy grzeczni jego koledzy odbywajacy z nim podróż nie wytrwali w powołaniu i zostali odesłani do domu, a on najgorszy - pozostał, ukończył szkołę średnią, odbył nowicjat, potem studia w Rzymie, został wyświęcony na księdza i został prowincjałem ${ }^{16}$. To świadectwo Michała Kobucha pomogło wielu saletynom przezwyciężyć różne kryzysy w powołaniu zakonnym i kapłańskim.

Nowicjat rozpoczął 8 września 1911 r. w Suzie (Włochy) pod kierunkiem świątobliwego mistrza ks. Ludwika Beaup i socjusza ks. Wiktora Hostach $y^{17}$. Rygorystyczne przestrzeganie wszelkich zarządzeń w nowicjacie nie dla każdego jest łatwe do zaakceptowania. Michał, przyzwyczajony do dyscypliny w Małym Seminarium, bez trudu podporządkował się wymaganiom obowiązującym w zakonie. Lubił karność i sprężystą organizację, a wyrzeczenia i stała praca nad sobą nie przerażały go wcale. Życie w nowicjacie było mu miłe i czuł się szczęśliwym, pełen nadziei i ufności w świetlaną przyszłość. Ten promienny optymizm, dzięki któremu będzie szedł przez życie $\mathrm{z}$ uśmiechem, nie upadając na duchu w najcięższych nawet momentach, już w nowicjacie pozwalał mu cieszyć się każdym dniem, choćby nużącym i trudnym. Sprawy swej formacji zakonnej Michał traktował bardzo świadomie i rzetelnie. Lubil na te tematy rozmawiać z nowicjuszami, dzieląc się swymi spostrzeżeniami ${ }^{18}$.

Michałowi szybko upłynałł rok formacji w nowicjacie. Pierwszą profesję zakonną na trzy lata złożył 8 września 1912 r. w kaplicy domowej w Suzie na ręce generała ks. Józefa Perrin. W roku szkolnym 1912/1913 pozostał nadal w Suzie, gdzie studiował re-

tęsknota za krajem rodzinnym. AZSR, syg. XXI-E-1f, Annales de la résidence de Tountai (1901-1911), s. 33-39.

${ }^{15}$ AZSR, syg. XIX-F-1s, Grand Registres Le Souste Tournai (1884-1917); syg. XIX-F-1t, L'Ecole Apostolique de Toumai - Grand Registre; syg. XXI-E-1f, Annales...; syg. XIX-F-1u, Tournai - Notes (1904$-1912)$.

${ }^{16}$ F. Daniol, Ks. Michat Kolbuch, „PMBS-USA”, R. 53:1987, nr 7-8, s. 8.

${ }^{17}$ AZSR, syg. XV, L. Beaup, Notes de Noviciat La Salette 1902-1924; syg. XIX-D-b1, J. Imhof, Notice necrologique du R. P. Michel Kolbuch, Rome 1958; syg. XIX-A-s, Statistiques Novices 1860-1934.

${ }^{18}$ Tamże. 
torykę i przygotowywał się do matury ${ }^{19}$. Po uzyskaniu egzaminu dojrzałości w $1913 \mathrm{r}$. został skierowany we wrześniu tego samego roku na studia filozoficzno-teologiczne do Rzymu, na Uniwersytet Gregoriański (1913-1915). Przedtem jeszcze w czasie wakacji odbyl krótką wizytę w domu rodzinnym ${ }^{20}$. W czasie studiów kleryk Michał otrzymał tonsurę w dniu 11 kwietnia 1914 r. w bazylice św. Jana na Lateranie z rąk kard. Bazylego Pompili, wikariusza Rzymu i protektora zgromadzenia. Wkrótce jego studia filozoficzne zostały zakłócone przez pierwszą wojnę światowa. Gdy w 1915 r. Włochy wypowiedziały wojnę Austrii, kleryk Michał wraz z kilkoma innymi kolegami, poddanymi cesarza austriackiego, został internowany na Sardynię. Jednak i w tych trudnych warunkach nie stracił bezcennego czasu lecz studiował prywatnie i zdawał egzaminy w diecezjalnym Wyższym Seminarium Duchownym w Algherro na Sardynii ${ }^{21}$. Najpierw ukończył filozofię, a następnie pierwszy rok teologii. Dzięki interwencji Stolicy Apostolskiej u rządu włoskiego udało mu się powrócić na wiosnę 1916 r. do Rzymu, aby dalej kontynuować studia teologiczne na Uniwersytecie Gregoriańskim. W tym czasie przyjął święcenia niższe, które udzielił mu 24 marca i 7 kwietnia 1916 r. kard. Pompili w swej prywatnej kaplicy w Rzymie.

Nadal studiował zagadnienia teologiczne na Uniwersytecie Gregoriańskim w Rzymie w latach 1916-1919, gdzie został bakalariuszem filozofii i teologii. Podczas trwania studiów na stałe złączył się ze zgroumadzeniem i przyjął poszczególne stopnic święceń kapłańskich. Profesję wieczystą złożył 15 sierpnia 1916 r. w kaplicy zgromadzenia w Salmacie na ręce przełożonego ks. Celestina Crozet. Subdiakonat otrzymał 6 maja 1917 r. u Księży Misjonarzy w Rzymie, a 16 września 1917 r. diakonat w kaplicy saletynów w Salmacie, z rak ordynariusza diecezji Nocera, bpa Nicola Cola ${ }^{22}$. Chociaż nie ukończył jeszcze studiów teologicznych, Michał został wyświęcony na kapłana za specjalną dyspensą Stolicy Apostolskiej, w dniu 2 grudnia 1917 r. przez kard. Bazylego Pompili, w jego prywatnej kaplicy w Rzymie ${ }^{23}$. Ks. Michał Kolbuch był pierwszym saletynem polskiego pochodzenia. Zaznaczył to na obrazku prymicyjnym, dedykowanym współbratu zakonnemu, ks. Louis Carlier. Mszę prymicyjną odprawił w uroczystość św. Franciszka Ksawerego w bazylice św. Piotra na Watykanie, podczas której usługiwali mu klerycy - Polacy studiujący na Uniwersytecie Gregoriańskim ${ }^{24}$. Ks. Kolbuch doskonale znał pięć języków obcych, którymi się posługiwał w pracy misjonarskiej: francuski, angielski, włoski, niemiecki i rosyjski ${ }^{25}$.

${ }^{19}$ AZSR, syg. XXVIII-E-2b, Annales Suse (1907-1928).

${ }^{20} 15$-lecie święceń kapłańskich ks. Michata Kolbucha, pierwszego polskiego misjonarza w zgronadzeniu OO. Saletyów, „PMBS-USA” R. 8:1932, nr 12, s. 258.

${ }^{21}$ AZSR, Notice necrologique..., s. 1.

${ }^{22}$ APSK, Ksiega święcen Zgromadzenia Misjonarzy Matki Bożej z La Salette w Polsce, t. 1:1917-1963.

${ }^{23}$ Tamże; AZSR, syg. XIX-E-H-d, Registre des Ordinations (1852-1925).

${ }^{24}$ Pod sztandarem Saletyńskiej Pani, „PMBS” R. 29:1949, nr 12, s. 341-342.

${ }^{25}$ AZSR, Renseignenents a fornir sur chaque profes Michel Kolbuch. 


\section{MISJONARZ I WYCHOWAWCA}

Po święceniach pozostał $w$ domu zakonnym Rzymie, aby dokończyć studia na Uniwersytecie Gregoriańskim. W maju 1919 r. ks. Kolbuch przyjechał do odrodzonej Polski, na krótki pobyt w czasie którego odwiedził swój dom rodzinny w Busku oraz klasztor w Dębowcu. Następnie 20 czerwca 1919 r. wyjechał z Polski do Suzy (Włochy) wraz z dziewięcioma wychowankami Małego Seminarium w Dębowcu, kandydatami do nowicjatu ${ }^{26}$. Począwszy od lipca 1919 do września 1920 r., ks. Kolbuch pełnił funkcję socjusza międzynarodowego nowicjatu saletyńskiego w Suzie (Włochy). Po roku formacyjnej pracy, jaką było zaprawianie młodych kandydatów do życia zakonnego i przygotowanie ich na gorliwych misjonarzy, powrócił do Polski. We wrześniu 1920 r. przyjechał do Polski, gdzie objął obowiązki nauczyciela i prefekta Małego Seminarium w Dębowcu k. Jasła. Z jego przyjazdem do Dębowca życie seminaryjne zdecydowanie ożywiło się. Nowy prefekt przedsiębiorczy, muzycznie uzdolniony i sam grający doskonale na instrumentach, założył chór mieszany z chłopców, urządzał przedstawienia teatralne oraz organizował wycieczki. Ludność Dębowca i okolicy ściągała coraz liczniej na nabożeństwa do kaplicy klasztornej nie tylko w celu posłuchania dobrego śpiewu, ale także dla płomiennych kazań o Matce Bożej Saletyńskiej ${ }^{27}$.

W klasztorze dębowieckim rozpoczął też działalność apostolską głosząc rekolekcje i misje parafialne na terenie całego kraju. W dniu 8 grudnia 1920 r. powołuje do życia bractwo „Związek Matki Bożej Saletyńskiej”28. Miało ono na celu nie tylko rozwijanie poprzez różne praktyki religijne pobożności maryjnej i szerzenie Orędzia z La Salette, ale również naśladowanie cnot Maryi, zwłaszcza Jej miłości ku Bogu i bliźnim. Bractwo miało swoje specjalne nabożeństwo ku czci Matki Bożej z La Salette, najpierw 19 dnia miesiąca, a potem w każdą trzecią niedzielę miesiąca. Z Dębowca i okolicy przybywali czciciele Maryi, by polecić wszystkie sprawy Tej, która nieustannie wstawia się za nami. Dlatego dość wcześnie zaczęła się wytwarzać praktyka pisania próśb i podziękowań, które składano przed Jej wizerunkiem, a następnie odczytywano publicznie w trzecie niedziele miesiąca i w maryjne święta. Napływały też podziękowania za otrzymane łaski od czcicieli Maryi zamieszkałych w różnych, nawet odległych od Dębowca, miejscowościach naszego kraju ${ }^{29}$. W dniu 5 marca 1921 r. za aprobatą bpa Józefa Sebastiana Pelczara, ordynariusza przemyskiego, bractwo „Związek Matki Bożej Saletyńskiej” wyznaczyło sobie dodatkowy cel: niesienie pomocy materialnej ubogim chłopcom, którzy w przyszłości pragną poświecić się pracy misjonarskiej w Zgromadzeniu Misjonarzy Matki Bożej z La Salette ${ }^{30}$.

${ }^{26}$ Byli to: Michal Bielak, Jan Helpa, Piotr Jaworski, Stanisław Kociuba, Władysław Pająk, Klemens Schleis, Franciszek Ślusarz, Ludwik Wolek i Stanisław Zajchowski. P. J a m i o 1, Saletyni Polsce, Kraków 2004, s. 85; 15-lecie święceń...

${ }^{27}$ Pod sztandarem..., s. 342.

${ }^{28}$ Archiwum Archidiecezjalne w Przemyślu (AAP), syg. TSal., Pismo bpa Józefa Sebastiana Pelczara, ordynariusza przemyskiego do ks. Eliasza Roux, superiora dębowieckiego, zezwalajace na erygowanie bractwa Zwiazek Matki Boskiej Saletyńskiej w Dębowcu (L. 4958), Przemyśl 8.12.1920; Statut „Zwiqzek Matki Bożej Saleryńskiej, czyli Grosz na powołania misjonarskie OO. Salețnów".

${ }^{29}$ P. J a m i of, Saletyni..., s. 273-274.

${ }^{30}$ AAP, syg. TSal., Pismo bpa Józefa Sebastiana Pelczara, ordynariusza przemyskiego do ks. Eliasza Roux, superiora dębowieckiego (L. 958), Przemyśl 5.03.1921. 
Ks. Michał Kolbuch we wrześniu 1921 r. ku uczczeniu 75-lecia objawienia Matki Bożej w La Salette rozpoczął wydawanie pisma pod tytułem „Posłaniec Matki Boskiej Saletyńskiej"31. Pismo to jako redaktor prowadził do roku 1923. Celem tego pisma była jednie cześć Matki Bożej Saletyńskiej przez rozkrzewianie Jej nauk i przestróg oraz rozszerzanie Jej kultu na polskiej ziemi. Pismo to w latach 1921-1925 ukazywało się jako dwumiesięcznik. Od roku 1926 jako miesięcznik. Poruszało problematykę dotyczącą historii saletynów, tematykę misyjną (sprawozdania z misji, listy misjonarzy), informowało o działalności bractw saletyńskich i kulcie Maryi z La Salette na polskiej ziemi, zawierało korespondencję z czytelnikami, kronikę dębowiecką, nekrologi, prośby i podziękowania do Matki Bożej Saletyńskiej, kalendarz miesięczny, artykuły o tematyce: maryjnej, hagiograficznej, intencje modlitewne oraz informacje ze świata katolickiego ${ }^{32}$.

W listopadzie 1921 r. ks. Michał Kolbuch założył „Arcybractwo Komunii świętej Wynagradzającej", aby rozbudzić ducha wynagrodzenia i ekspiacji Panu Bogu za nieświęcenie niedzieli i inne grzechy, wypomniane przez Maryję w La Salette. Impulsem do tego dzieła był wydany przez papieźa Piusa X, dekret De guotidiana SS. Eucharistiae sumptione (20 grudnia 1905), który zalecał wszystkim chrześcijanom częstą i codzienną Komunię świętą ${ }^{33}$. Dokument ten odbił się szerokim echem na lamach polskiej prasy katolickiej, był komentowany $w$ zarządzeniach diecezjalnych i przyczynił sic̨ w znacznej mierze do upowszechnienia praktyki częstej, a nawet codziennej Komunii świętej. W Dębowcu, przystępując do realizacji dekretu ks. Kolbuch wprowadził praktyke spowiadania wiernych 19 dnia każdego miesiąca oraz $w$ wigilie świąt uroczystych. Do tego celu wykorzystał „Posłańca”, w którym zamieszczał artykuły o Komunii św. wynagradzającej Panu Bogu za grzechy na cześć Maryi z La Salette 19 dnia każdego miesiąca ${ }^{34}$. Ks. Michał Kolbuch przed wprowadzeniem takiej formy kultu zwrócił się do Episkopatu Polski z prośbą o błogosławieństwo i aprobatę. Skutek apelu był bardzo pozytywny. W sumie 20 biskupów wyraziło gorące poparcie dla praktyki miesięcznej Komunii św. wynagradzającej ${ }^{35}$. A niektórzy z nich propagowali tę poboźną prakty-

${ }^{31}$ Postaniec posiadał format $32 \times 15,3 \mathrm{~cm}$, objętość 32 strony. Jego naklad wynosił w poszczególnych latach: 1921 - 2500 egz., 1923 - 20000 egz., 1926 - 23000 egz., 1929 - 18000 egz., 1932 - 23000 egz., 1935 25000 egz., 1939 - 25000 egz., 1946 - 10000 egz., 1948 - 12000 egz., 1950 - 9000 egz.

${ }^{32}$ Por. Bibliografia katolickich czasopism religijnych w Polsce 1918-1939, oprac, i red. ks. Z. Zieliński, Lublin 1981, s. 226; „PMBS”, z lat 1921-1950; APSK, Dokumenty dotyczace „Postańca”: Pismo ks. Bronisława Mbnarskiego MS do Państwowych Krakowskich Zakładów Graficznych w Krakowie, Kraków 26.06.1950; R. Wo j u n i k, Rodzaje dzialalności Zgromadzenia 1939-1947, Kraków 1974, s. 1; AZSR, syg. G 25-1II-VI, Circulaires des Péres Gènéraux, t. 3:1920-1926, t. 4:1926-1932, t. 5:1932-1938, t. 6:1938-1950; ASD, Gazetowa ksiqżka nadawcza czasopisma „Postaniec Matki Boskiej Saleryńskiej” 1936-1950.

${ }^{33}$ Por. D. O ls z e w sk i, Polska kultura religijna na przetomie XIX i XX wieku, Warszawa 1996, s. 179 .

${ }^{34}$ „PMBS", R. 2:1922, nr 2, s. 34-35.

${ }^{35}$ Byli to: abp Wawrzyniec Lauri, nuncujusz apostolski; ks. kard. Aleksander Kakowski, metropolita warszawski; abp Bolesław Twardowski, metropolita lwowski; bp Józef Sebastian Pelczar, ordynariusz przemyski; bp Karol Józef Fischer, sufragan przemyski; abp Karol Hryniewiecki, metropolita wileński; bp Piotr Mańkowski, ordynariusz kamieniecki; bp Stanisław Kazimierz Zdzitowiecki, ordynariusz kaliskokujawski; bp Augustyn Łosiński, ordynariusz kielecki; bp Henryk Przeździecki, ordynariusz podlaski; bp Marian Leon Fulman, ordynariusz lubelski; bp Jerzy Kolek, wikariusz generalny dla Śląska Cie- 
kę na terenie swoich diecezji. Biskup Józef Sebastian Pelczar, ordynariusz przemyski, zatwierdził kanonicznie nabożeństwo Miesięcznej Komunii św. wynagradzającej 19 dnia każdego miesiąca na cześć Maryi Saletyńskiej w dniu 27 listopada 1922 r. ${ }^{36}$ Od tej chwili w wielu parafiach umieszczano w kościołach figury i obrazy Matki Bożej Saletyńskiej, a proboszczowie prosili saletynów o wprowadzenie tego nabożeństwa ${ }^{37}$.

Z myślą o rozpowszechnianiu tej pobożnej praktyki na polskiej ziemi w $1923 \mathrm{r}$. ks. Kolbuch napisał broszurę ${ }^{38}$, w której zachęcał wiernych do dobrowolnych aktów pokuty i przyjmowania Komunii św. wynagradzającej. Powołując się na objawienie Najświętszego Serca Pana Jezusa św. Małgorzacie Alacogue (1647-1690) oraz istniejącą praktykę pierwszych piątków miesiąca, ks. Kolbuch udowodnił, że zadośćuczynienie jest miłe Bogu jako potrzeba ludzkiego serca. Również widok płaczącej Matki Bożej z La Salette i jej słowa jako Pośredniczki i Orędowniczki pobudzają wszystkich do przemiany życia i nasuwają myśl wynagrodzenia ${ }^{39}$. Aby zrealizować to dzieło, które wzbudził Duch Święty ks. Kolbuch każdego miesiąca zbierał wiernych w kaplicy klasztornej w Dębowcu na całodzienną adorację, połączoną ze Mszą św. i Komunią wynagradzająca ${ }^{40}$. Od tej chwili praktyka Komunii św. wynagradzającej łączyła się w Dębowcu ze spowiedzią i całodzienną adoracją Najświętszego Sakramentu ${ }^{41}$. W krótkim czasie rozszerzył to dzieło w całej Polsce otrzymując na nie błogosławieństwo niemal wszystkich ówczesnych biskupów polskich. Szczególną rolę w rozwoju praktyki Komunii świętej wynagradzającej odegrał „Posłaniec”. Czasopismo to zalecato tę praktykę i zamieszczało na swoich łamach informacje o inicjatywach częstej Komunii świętej podejmowanych w środowiskach parafialnych różnych diecezji polskich. Z korespondencji „Posłańca” dowiadujemy się, że wiele miejscowości praktykowało Komunię świętą wynagradzającą w trzecią niedzielę każdego miesiąca ${ }^{42}$.

szyńskiego; bp August Hlond, administrator apostolski dla Górnego Śląska; bp Władysław Krynicki, sufragan kalisko-kujawski; bp Stanisław Kostka Łukomski, sufragan poznański: bp Romuald Jałbrzykowski, sufragan łomżyński; bp Czesław Sokołowski, sufragan podlaski; bp Adolf Józef Jełowicki, sufragan lubelski; bp Paweł Kubicki, sufragan sandomierski; bp Adolf Piotr Szelążek, sufragan płocki. Zob. „PMBS” R. 3:1923, nr 2, s. 27; nr 3, s. 44-45; nr 4, s. 59-61.

${ }^{36}$ AAP, syg. TSal., Pismo biskupa Józefa Sebastiana Pelczara do ks. superiora Eliasza Roux (L. 5638), Przemyśl 27.11.1922.

${ }^{37}$ „PMBS”, R. 3:1923, nr 2, s. 29; nr 5, s. 78; La Communio réparatrice du 19 en Pologne, „Bulletin”, R. $22: 1923$, nr 252 , s. 220.

${ }^{3 B}$ M. K o l b u c h, Miesięczna Komunia wynagradzajaca na cześć Najśs. Panny Maryi Saletyńskiej 19- -go kaźdego miesiqca, Tarnów 1923.

${ }^{39}$ Tamże, s. 3.

${ }^{40}$ Od samego początku praktyka Komunii św. wynagradzającej rozwijała się szybko w Dębowcu i cieszyła się duźą frekwencją wiernych. Ks. A. Skibiński podaje, że w 1926 r. w każdy 19 dzień miesiąca przystępowało w kaplicy klasztornej do Komunii św. ponad 600 wiernych. Por. A. S k i b i ń s k i, La Salette en Pologne, „Bulletin”, R. 25:1926, nr 285, s. 170.

${ }^{41}$ AAP, syg. TSal., Pismo bpa ordynariusza w Przemyślu Józefa Sebastiana Pelczara do ks. superiora w Dębowcu Eliasza Roux zezwalające na wystawienie Najśw. Sakramentu w kaplicy klasztornej (L. 1035), Przemyśl 17.10.1921.

${ }^{42}$ Por. Korespondencja Postańca, „PMBS”, z lat 1921-1950. 


\section{DZIA A A NOŚĆ DUSZPASTERSKA W STANACH ZJEDNOCZONYCH}

W lipcu 1923 r. ks. Kolbuch został skierowany przez przełożonych do Stanów Zjednoczonych w celach misyjnych, gdzie miał pozostać do 1926 r. Ks. Kolbuch przyjechał do Ware i z tej saletyńskiej placówki wyjeżdżał z misjami do polskich parafii na terenie Stanów Zjednoczonych. Swą pracę misyjno-rekolekcyjną na terenie Stanów Zjednoczonych i otrzymanymi ofiarami z tego tytułu, pragnął pomóc rozpoczętym dziełom formacyjnym w Polsce: nowicjatowi, Małemu Seminarium i klerykatowi, a także wzmocnić działalność wydawniczą i misyjną ${ }^{43}$. W Ameryce rozwinął ks. Kolbuch szeroką działalność duszpasterską. W Ware pełnił obowiązki wikariusza (1923-1925) i misjonarza ludowego, głosząc rekolekcje i misje parafialne w polskich parafiach na terenie Stanów Zjednoczonych. W styczniu 1925 r. rozpoczął wydawanie w języku polskim miesięcznika „Posłaniec Matki Bożej Saletyńskiej”. W krótkim czasie zdobył 20 tysięcy abonentów. Później dołączył do tego pisma dodatek w języku angielskim. Obowiazki redaktora pełnił do 1930 r. W 1926 r. został mianowany przełożonym w rezydencji Ware, a w listopadzie 1927 r. proboszczem, po ks. Józefie Piszczałce ${ }^{44}$. Na stanowisku proboszcza, ks. Kolbuch pracował $\mathrm{z}$ wielkim poświęceniem dla dobra parafii, organizując różne towarzystwa i bractwa, a także starał się utrzymać na wysokim poziomie życie religijne, moralne i patriotyczne wśród 2700 rodaków ${ }^{45}$.

Jako proboszcz przyczynił się do odnowy moralnej swoich parafian poprzez wprowadzenie miesięcznego dnia rekolekcyjnego. W dniu 19 każdego miesiąca parafianie przystępowali do spowiedzi i Komunii św. wynagradzającej. W 1929 r. zorganizował pierwszą polsko-amerykańską pielgrzymkę na miejsce objawienia w La Salette i do Polski. W 1931 r. rząd Polski zlecił mu zarząd wydawnictwa „Poland America”, które promowało Polskę w opinii amerykańskiej. Był to ilustrowany miesięcznik będący wówczas jedynym pismem polskim w Ameryce w języku angielskim, którego celem było szerzenie znajomości polskich spraw. Jego wydawcą był ks. Michał Kolbuch, a redaktorem p. Ignacy Mościcki. Pismo ukazywało się w 9 tysiącach egzemplarzy. Dla znalezienia środków materialnych dla tej publikacji, ks. Kolbuch udał się wiosną 1932 roku do Polski, aby jako wydawca „Poland America” zapoznać rząd polski i społeczeństwo z tym dziełem. Gdy nie otrzymał koniecznej pomocy materialnej, wówczas pismo „Poland America” zbankrutowało. W 1934 r. założył miesięcznik saletyński „The Messenger of Our Lady of La Salette", wydawany w języku angielskim dla czcicieli Maryi z La Salette na terenie Ameryki Północnej ${ }^{46}$. Ks. Kolbuch posługę proboszcza i przełożonego w Ware pełnił do końca stycznia 1934 r., kiedy to został mianowany prowincjałem nowoutworzonej prowincji polskiej z siedzibą we Lwowie.

${ }^{43}$ AZSR, Notice necrologique..., s. 2.

${ }^{44}$ AZSR, syg. G 10-IV, Księga uchwat rady generalnej, t. 4:1909-1933.

${ }^{45}$ 15-lecie święceń..., s. 260.

${ }^{46}$ Wielka wiadomość. Przew. ks. Michat Kolbuch MS, przetożony polskich OO. Misjonarzy w Ware, Mass., USA, mianowany pierwszym prowincjatem nowoutworzonej polskiej prowincji, „PMBS-USA" R. 10:1934, nr 4, s. 100 . 


\section{PROWINCJAE}

Wcześniej, bo w 1932 r., ks. Kolbuch został delegatem na kapitułę zgromadzenia i brał udział w obradach kapituły generalnej od 15 do 28 sierpnia 1932 r. w Noirétable N. D. de l'Hermmitage (Francja) ${ }^{47}$. W wyniku podjętych przez nią decyzji podziału zgromadzenia na prowincje, po zatwierdzeniu tej uch wały przez Stolicę Apostolska, ks. Michał Kolbuch został mianowany 9 lutego 1934 r. pierwszym polskim prowincjałem. W dniu 9 czerwca 1934 r. ks. prowincjał Michał Kolbuch wyjechał z Nowego Jorku na okręcie „Conte di Savoia” do Polski, aby objąć obowiązki prowincjała polskiej prowin$\mathrm{cji}^{48}$. Po przybyciu do Polski zamieszkał na placówce saletyńskiej we Lwowie. O tej chwili rozpoczął niezwykle pracowity okres życia, w którym niewiele było czasu na odpoczynek. Najpierw gościł we wszystkich domach prowincji, wygłaszając programowe konferencje, w których zachęcał swoich współbraci do współpracy w budowaniu wspólnoty prowincjalnej w duchu miłości, jedności i w pojednanu. Trzeba zaznaczyć, że na urząd prowincjała został powołany człowiek niezwykle dynamiczny. Jego pasją było życie wewnętrzne oraz praca apostolska. Jego atutami były: wybitna inteligencja, otwartość na potrzeby czlowieka, zmysł organizacyjny, znajomość warunków apostołowania we współczesnym świecie oraz bogate doświadczenie. Bogaty wewnętrznie, myślący głęboko teologicznie, był także pasjonatem instytucjonalizmu zakonnych zasad i zachowania reguły. Pełen kultury i szacunku w relacjach z biskupami, duchowieństwem diecezjalnym i zakonnym. Ścisły w myśleniu i przekazie kerygmatycznym. W pierwszym liście okólnym skierowanym do wszystkich członków prowincji złożył hołd swoim poprzednikom, przełożonym regionalnym: ks. dr Salomonowi Schalbetterowi i ks. dr Michałowi Bielakowi. Szczególnie ciepło i z uznaniem wyraził się o ojcu i założycielowi dzieła saletyńskiego na polskiej ziemi ks. Salomonie Schalbetterze (1873-1934): „Ceniliśmy go wszyscy i kochali. Mieliśmy do niego pełne zaufanie i patrzyliśmy na niego jak na ojca, przyjaciela, przewodnika i mistrza. Był dla nas uosobieniem dobroci, szlachetności, sprawiedliwości i gorliwości zakonnej" ${ }^{\text {'49 }}$. Wobec siebie i współbraci z wielką pokorą wyznał, że nie może się równać ze swoimi mistrzem - jak o nim stale się wyrażał. Osądził się zbyt surowo, nazywając się kruchym narzędziem i małym pastuszkiem Maryi z La Salette ${ }^{50}$. Z wielkim szacunkiem wypowiadał się o współbraciach, zwłaszcza pionierach na polskiej ziemi. Był świadom, że nie od niego zaczynają się nowe dzieje i nowa epoka saletyńska. On chciał jedynie kontynuować dotychczasowe dzieła i nadać im jeszcze większy rozmach.

Zdawał sobie sprawę, że kreślenie programu dla prowincji w pierwszym okólniku jest jeszcze za wcześnie. Dlatego ogólnie stwierdził, że najpilniejszym zadaniem prowincji będzie uporządkowanie kilku spraw: „Przede wszystkim wszyscy zakonnicy muszą się starć o wierność regule i jej duchowi. Cenić rady ewangeliczne i nimi żyć na co dzień, dając światu świadectwo radykalnego życia. Następnym zadaniem będzie

\footnotetext{
${ }^{47}$ 15-lecie święceń..., s. 259.

48 „PMBS-USA“, R. 10:1934, nr 5, s. 130.

${ }^{49}$ Archiwum klasztoru Misjonarzy Matki Bożej z La Salette w Dębowcu (ASD), Rada Prowincjalna - Okólniki, t. 1:1931-1951, Okólnik nr 1.

${ }^{50}$ Tamże.
} 
rozwój życia modlitwy. To takie charakterystyczne pytanie dla wspólnoty saletyńskiej postawiła Maryja w La Salette: «Czy dobrze się modlicie moje dzieci?». Jestem szczęśliwy, że wkraczamy w okres, w którym tak wspaniale i wprost cudownie rozwija się nabożeństwo do Matki Bożej Saletyńskiej na polskiej ziemi"51. Poruszył także ważny wymiar saletyńskiego charyzmatu, jakim było od czasu powstania zgromadzenia w 1852 r. pokuta i pojednanie, zachęcając wszystkich do życia tym darem ${ }^{52}$. Oczywiście życie dyktowało swoje wyzwania, które były na nowo interpretowane, a prowincjał musiał coraz bardziej schodzić z wysokości ideałów ku jego konkretom. W następnym okólniku, skierowanym do prowincji związku z nominacjami przełożonych we wszystkich domach zakonnych, wzywał do posłuszeństwa na wzór Boskiego Mistrza i Patronki zgromadzenia - Matki Bożej z La Salette ${ }^{53}$. Przez prawie 16 lat swojego prowincjalatu napisał wiele listów okólnych do prowincji, a także wygłosił ogromną ilość kazań, różnych przemówień i konferencji z okazji rozmaitych uroczystości. Zawsze jego troską było dobro zgromadzenia i dzieł misyjnych, a przede wszystkim życie duchowe każdego z podwładnych. Z jego pism i homilii dają się odczytać wszystkie problemy prowincji oraz przemiany zachodzące w świecie wraz $z$ ich teologiczną i ascetyczną ocena, a także wielka troska prowincjała, który czuł się odpowiedzialny przed Bogiem za powierzonych mu zakonników. Znaleźć tam można przestrogi i napomnienia, rozporządzenia i dzielenie się problemami. Są wreszcie prośby o odnowę życia zakonnego $\mathrm{i}$ intensywniejszą modlitwę $e^{54}$.

Ks. Michał Kolbuch jako prowincjał bardzo pilnie i solidnie wizytował domy zakonne, rozmawiał z każdym zakonnikiem, zwracał uwagę, krytykował i cieszył się z osiagnnięć poszczególnych placówek i wspólbraci. Miał jednak świadomość, że wizytacja to jeszcze nie wszystko. Może ona wypaść pięknie, a w domu można zachować wszystkie przepisy reguły, ale istota życia zakonnego ukryta jest we wnętrzu każdego z zakonników, a nie tylko w ich zewnętrznym sposobie bycia. Trzeba żyć w zjednoczeniu z Bogiem, doskonalić się w cnotach, a na co dzień promieniować miłością bliźniego. Trzeba mocno podkreślić, że wizytacje prowincjała, ks. Kolbucha były dla wspólnot czasem refleksji, modlitwy, korekty i odnowy. Szansę na owocny ich przebieg dawała scentralizowana struktura władzy, w miarę jednorodna aktywność apostolska oraz duchowy i braterski klimat wizytacji ${ }^{5 s}$. Ks. Kolbuch prowadził niezwykle aktywne życie apostolskie. Gdy przegląda się dokumentację źródłową, rodzi się pytanie, jak jeden człowiek mógł mieć tyle sił, zdrowia i mocy psychicznych, by tyle pracować i prowadzić taki właśnie tryb życia. Czy przesadzał? Trudno dziś dać obiektywną odpowiedź. Jedno jest pewne, że posiadał niespożyte siły, nie odmawiał żadnej pracy, zwłaszcza dla kleryków i nowicjuszów. Podkreślenia godnym jest fakt, że do wszystkich rekolekcji był znakomicie przygotowany. Konferencje wcześniej przygotowywał na piśmie. Większość jego rekolekcji, konferencji ascetycznych, zachęt i egzort oparta

\footnotetext{
${ }^{51}$ Tamże.

${ }^{52}$ Tamże.

${ }^{53}$ ASD, Rada Prowincjalna - Okólniki, t. 1:1931-1951, Okólnik nr 2.

${ }^{54}$ ASD, Rada Prowincjalna - Okólniki, t. 1:1931-1951.

${ }^{55}$ APSK, Wizytacje prowincjalskie z lat 1934-1950.
} 
była na tekstach św. Pawła Apostoła. Mówił z wielką pasja, a wszystko poparte było świadectwem życia misjonarza ${ }^{56}$. Oprócz wspomnianych zajęć wyjeżdżał także na rekolekcje i misje parafialne.

Pierwszą troską duszpasterską nowego prowincjała było rozpoczęcie budowy sanktuarium Matki Bożej Saletyńskiej w Dębowcu. Na ten cel zbierał już od kilku lat ofiary w Stanach Zjednoczonych i w Kanadzie. W lipcu 1934 r. utworzył prowincjalny referat rekolekcyjno-misyjny. Pierwszym jego dyrektorem został ks. prowincjał Michał Kolbuch, który zorganizował w 1935 r. pierwszą stałą grupę misjonarską w dziejach naszej prowincji. Należeli do niej sami znani misjonarze i wybitni kaznodzieje, jak: ks. prowincjał Michał Kolbuch, rezydujacy we Lwowie, ks. Julian Filoda, ks. Tadeusz Ptak i ks. Stanisław Krzyworączka - wszyscy przebywający w Dębowcu, oraz ks. Józef Sroka, rezydujący w Hurku. Misjonarze ci, jak podaje Kronika Zgromadzenia, byli gorliwymi głosicielami Słowa Bożego i nigdy nie odczuwali zmęczenia w pracy apostolskiej $^{57}$.

Ks. Michal Kolbuch rozwinął bogatą działalność nie tylko jako prowincjał, lecz również jako misjonarz ludowy, wespół z takimi saletynami, jak: Tadeusz Ptak, Bronisław Młynarski, Stanisław Pienta, Klemens Schleis, Ludwik Wołek i Jozef Sroka. Zainicjowal też w 1935 r. we Lwowie wydawane tematycznej ulotki religijnej $Z$ yj po Bożemu. Pierwszym redaktorem mianował ks. Józefa Paprockiego, a po nim księży Franciszka Czarnika i Alojzego Gandawskiego. Początkowo nakład pisma wynosił 50 tysięcy, a później gwałtownie wzrósł od 200 do 500 tysięcy egzemplarzy ${ }^{58}$. Było to wielkie dzieło saletynów dające odpowiedź na szerzący się materializm w prasie lewicującej i będące skutecznym środkiem zwalczania wrogich Kościołowi poglądów. Ulotki były rozsyłane w paczkach po 100 egzemplarzy w cenie 50 groszy za paczkę do księży proboszczów. Proboszczowie rozpowszechniali je wśród swoich parafian. Wielu polskich biskupów ${ }^{59}$ polecało swojemu duchowieństwu kolportaż tego pisma oraz dziękowało ks. Michałowi Kolbuchowi za tę pożyteczną inicjatywę ${ }^{60}$. Pismo ${ }^{61}$ to poruszało następującą problematykę: ideały chrześcijańskie w życiu społecznym i wychowanie katolickie, walka $\mathrm{z}$ tendencjami antychrześcijańskimi w wychowaniu, polemika na tematy religijne. Było to wielkie wydarzenie w czasach szerzenia się poglądów materialistycznych propagowanych w prasie komunistycznej. Wielka liczba parafii zamawiała i rozprowadzała wśród wiernych dużą ilość wspomnianych ulotek. Był to jeden z najskuteczniejszych środków zwalczania wrogich Kościołowi poglądów ${ }^{62}$.

${ }^{56}$ ASPK, Kronika Zgromadzenia Misjonarzy Maıki Bożej z La Salette w Polsce (Kr.ZSP), t. 2:1902$-1952$.

${ }^{57}$ APSK, Ksiegga uchwat rady prowincjalnej, t. 1:1926-1966; Kr.ZSP, t. 2:1902-1952.

${ }^{58}$ F. D a n i o ł, Ks. Michat Kolbuch..., s. 13.

${ }^{59}$ Wśród biskupów polskich wielką gorliwością odznaczał się bp Franciszek Barda, ordynariusz przemyski, który nakazal wszystkim proboszczom rozprowadzanie ulotki „Żyj po Bożemu”. AAP, syg. TSal., Pismo bpa ordynariusza w Przemyślu Franciszka Bardy do ks. prowincjata Michata Kolbucha we Lwowie (L. 101/36), Przemyśl 10.01.1936.

${ }^{60}$ F. D a n i o 1, „Postaniec” sam o sobie, „PMBS-USA”, R. 67:1991, nr 5, s. 31.

${ }^{61}$ Ulotka „Żyj po Bożemu” posiadała format $16 \times 10,2 \mathrm{~cm}$, objętość 2 strony. Bibliografia katolickich..., s. 358.

${ }^{62}$ ASD, Zob. „Żyj po Bożemu”, z lat 1935-1939. 
Innym ważnym dziełem ks. Michała Kolbucha była troska o otwarcie działalności Małego Seminarium w Dębowcu. Należy tutaj przypomnieć, że sierpniu 1932 r. ze względu na trudności ekonomiczne zamknięto Małe Seminarium w Dębowcu. Najstarsi uczniowie zostali przyjęci do nowicjatu, a pozostałych zawiadomiono podczas wakacji, że szkoła została zamknięta i mają szukać sobie innej. Powodem zamknięcia Małego Seminarium w Dębowcu był kryzys ekonomiczny, jaki dotknął wówczas gospodarkę naszego kraju, a także źle prowadzona polityka ekonomiczna przez saletynów. Ówczesny ks. ekonom dębowiecki ulokował fundusze w prywatnym banku żydowskim Kornfelda z Jasła, aby mieć większe odsetki. Bank zbankrutował, jego wlaściciel rzekomo zastrzelił się, a saletyni zostali bez środków do życia. Dodatkową przyczyną która miała wpływ na rozwiązanie Małego Seminarium, to bankructwo pisma „Poland America" redagowanego w USA przez ks. M. Kolbucha. Dlatego rozwiązano Małe Seminarium, odsyłając do domów rodzinnych dwa roczniki. Wielu z odesłanych wstapiło do innych zakonów lub zostało przyjętych do szkół diecezjalnych ${ }^{63}$.

W celu znalezienia środków materialnych dla ponownego otwarcia Małego Seminarium w Dębowcu, ks. Kolbuch udał się w 1936 r. do Stanów Zjednoczonych. Zebrane prze ks. Kolbucha ofiary zdecydowanie przyczyniły się do otwarcia we wrześniu 1937 r. Małego Seminarium w Dębowcu. W dniu 1 września 1937 r. otwarto ponownie Małe Seminariun w Dębowcu. Inicjatorem i organizatorem szkoły był ks. dr Józef Szczepański. On też został jej dyrektorem, a prefektem ks. Władysław Czosnek. Oprócz dyrektora i prefekta zajęcia prowadzili: ks. dr Andrzej Czeluśniak, ks. dr August Gautier, ks. dr Franciszek Dantin, ks. Roman Wojtunik i Władysław Trzeciak. Spośród 100 kandydatów, po egzaminie konkursowym, który odbył się pod koniec czerwca, przyjęto 25 uczniów. Takie same liczebnie grupy przyjęto w dwóch następnych latach, z tym, że przyjęci na rok szkolny 1939/1940, nie rozpoczęli nauki ${ }^{64}$. Zgłosiło się znowu sporo chętnych uczniów, jednak wybuch drugiej wojny światowej przeszkodził w rozwoju tego dzieła. W dniu jej wybuchu, 1 września 1939 r., Małe Seminarium w Dębowcu liczyło ponad 70 uczniów. Po raz kolejny los przekreślił wielu chłopcom drogę do kapłaństwa w szeregach zakonnych saletynów ${ }^{65}$.

W tym miejscu należy wspomnieć, że ks. Kolbuch podczas pobytu w USA odwiedził również Amerykę Południowa, w szczególności ośrodki polskie, z myślą wysłania tam polskich misjonarzy. Do podjęcia takich planów przyczynił się rząd Polski, który wystapił z prośbą o księży dla Polaków mieszkających w Argentynie. W dniu 6 Iutego 1937 r. z inicjatywy rady prowincjalnej i za zgodą rady generalnej otwarto

${ }^{63}$ F. D a n i o 1, Okruchy historii. Dzieje Niższego Seminarium Duchownego Misjonarzy Matki Bożej Saletyńskiej w Polsce, „PMBS-USA” R. 65:1989, nr 10, s. 11; K. Z i e l i ń s k i, 100 Lat Banku Spótdzielczego w Jaśle, dawnego towarzystwa Zaliczkowego 1874-1974, „Roczni Jasielski”, t. 3:1990, s. 51-87; APSK, Katalog główny ocen klasy siódmej Matego Seminarium Księży Saletynów w Dębowcu za rok szkolny $1931 / 1932$.

${ }^{64}$ APSK, Katalog główny acen klasy pierwszej i drugiej Matego Seninarium Misyjnego Księży Saletynów w Dębowcu za rok szkolny 1938/1939.

${ }^{65}$ P. J a m i oł, Dzieje sanktuarium Matki Bożej Saletyńskiej w Dębowcu w latach 1910-1996, Kraków 2002, s. 232-233; t e n ż e, Saleryni..., s. 291. 
fundację w Argentynie. Twórcą tego dzieła był niezmordowany ks. prowincjał Michał Kolbuch, który po nieudanej próbie otwarcia fundacji w Brazylii, postarał się o założenie dzieła saletyńskiego w Argentynie. Myśl o pracy polskich saletynów w Argentynie zrodzila się w głowie ks. Michała Kolbucha podczas wizyty w 1935 r. u prezydenta Rzeczypospolitej, Ignacego Mościckiego. Wówczas ks. M. Kolbuch przedstawił prezydentowi grupę amerykańskich kleryków (34) i sióstr zakonnych (40) pochodzenia polskiego, która przywiózł do Polski w tym celu, aby studiując na polskich uczelniach udoskonalili język polski oraz poznali duchowość i kulturę polską ${ }^{66}$. Po otrzymaniu zgody od prezydenta, klerycy i siostry zakonne zostały skierowane na polskie uczelnie. Kilku kleryków studiowało w Instytucie Filozoficzno-Teologicznym w Dębowcu. Jednak eksperyment ten nie zdał egzaminu z powodu trudności zwiąanych z asymilacją amerykańskich kleryków i sióstr zakonnych. Ks. Michał Kolbuch przedstawił projekt fundacji w Argentynie najpierw prezydentowi, następnie Prymasowi Polski, ks. kard. Augustowi Hlondowi i po otrzymaniu pozwolenia i błogosławieństwa przystapił do dzieła. Już 7 listopada 1935 r. rada prowincjalna, po otrzymaniu pozytywnej opinii od władzy kościelnej, upowaźniła ks. Kolbucha do podjęcia starań w sprawie nowej fundacji w Argentynie ${ }^{67}$.

W dniu 8 kwietnia ks. Edward Sudyka wraz z ks. prowincjałem Michałem Kolbuchem wyjechał do Argentyny z portu Le Havre na okręcie francuskim. Po 28 dniach podróży znaleźli się 6 maja w Buenoes Aires. Ks. Edward Sudyka był pionierem fundacji w Argentynie. Początki misji były trudne, ponieważ saletyni nie mieli własnego kościoła ani mieszkania. Ponadto prawo argentyńskie nie zezwalało na tworzenie parafii narodowych polskich. Początkowo ks. Edward Sudyka mieszkał w hotelu, a później wynajął mieszkanie bez mebli w dzielnicy Dock Sud. Z pomocą przyszedł abp Alberti, który powierzył mu 16 czerwca w opiekę duszpasterską parafię św. Józefa na przedmieściu Villa Dominico (archidiecezja La Plata), położoną blisko dzielnicy Dock Sud. Od tej chwili ks. Sudyka obsługiwał tę parafię oraz odprawiał Mszę św. dla Polaków w kościele sercanów w Dock Sud ${ }^{68}$. W tym czasie ks. Sudyka uczył się języka hiszpańskiego i przygotowywał miejsce dla następnych misjonarzy. Byli nimi kolejni saletyni: ks. Władysław Pykosz (proboszcz Rosario), ks. Józef Paprocki (proboszcz Santa Fé), ks. Kazimierz Kornafel (wikariusz Villa Dominico), ks. Alojzy Zawisza (proboszcz Cordoba), br. Jan Maszczak (Villa Dominico) i br. Wojciech Cieślak (Villa Dominico). Ks. Józef Paprocki wyjechał do Argentyny w miejsce ks. Bronisława Młynarskiego, który zrezygnował $\mathrm{z}$ wyjazdu ze względów zdrowotnych ${ }^{69}$.

Powróćmy jednak do ks. Michała Kolbucha. Obowiązki prowincjała pełnił on do roku 1950. W latach 1935-1939 był dyrektorem prowincjalnego referatu powołaniowego. Troszczył się o powołania saletyńskie poprzez organizowanie tzw. akcji powołanio-

${ }^{66}$ A. G a n d a w s k i, Historia Zgromadzenia Księży Saletynów w Polsce, Kraków 1948, s. 24-25, praca mgr w: APSK; P. Jamiol, Saleryni..., s. 296, 301.

${ }^{67}$ P. J a m i o 1, Saletyni..., s. 301.

${ }^{68}$ E. S u d y k a, Wspomnienia z Argentyny, „Unitas", nr 12:1971, s. 12-28; APSK, Ksiega uchwat rady prowincjalnej, t. 1:1926-1966.

${ }^{69}$ APSK, Ksiega uchwat rady prowincjalnej, t. 1: 1926-1966; F. D a n i o 1, Ks. Michat Kolbuch..., s. 15; P. J a m i o I, Saletyni..., s. 303. 
wych na terenie Polski. Jego promieniujący duch apostolski przyczynił się do odkrycia powołania zakonnego u wielu polskich dziewcząt. Dowodem tego jest fakt, że w roku 1938 zwerbowal sześć kandydatek do Zgromadzenia Misjonarek Matki Bożej z La Salette i osobiście towarzyszył im w podróży do nowicjatu w Soissons (Francja) ${ }^{70}$. Jako prowincjał czynił wiele dla podniesienia stanu duchowego i materialnego saletynów w Polsce. W 1937 r. założył dzieło saletyńskie w Argentynie oraz przyczynił się do wysłania w 1938 r. ks. Władysława Czosnka na Madagaskar ${ }^{71}$ oraz kilku saletynów do Argentyny, USA i Kanady. Wzbogacił polską prowincję o dwie nowe placówki w Rzeszowie $(1936)^{72}$ i w Ostrowcu Świętokrzyskim $(1938)^{73}$. Jeszcze więcej starań podejmował dla odnowy ducha zgromadzenia, aby saletyni żyli duchem pojednania. Jego działalność, zwłaszcza w tej drugiej dziedzinie sprawiła, że zraził sobie wielu konfratrów. Przyjmowany początkowo $\mathrm{z}$ entuzjazmem, po kilku latach zawiódł oczekiwania spodziewających się wygodnego życia, bo chciał, by saletyni żyli duchem La Salette. Jego ideał życia został zrozumiany i przyjęty tylko przez niektórych saletynów ${ }^{74}$.

Gdy wybuchła druga wojna światowa, ks. Kolbuch 12 września 1939 r. opuścił Polskę i wyjechał z Lwowa. Przekroczył on granicę rumuńską z wojskiem polskim i udał się do Włoch i Francji, a stamtąd z Marsylii wyjechał w dniu 27 września 1939 r. na ostatnim okręcie amerykańskim do Stanów Zjednoczonych ${ }^{75}$, aby bronić tam polskiej sprawy i pracować dla odnowy prowincji polskiej. Do Stanów Zjcdnoczonych przybył w październiku 1939 r., gdzie pozostał do końca wojny. Celem jego wyjazdu było przygotowanie zaplecza materialnego i personalnego dla polskiej prowincji. Tam też utworzył nową radę dla prowincji polskiej, a jej delegatem w kraju na czas wojenny zamianował superiora dębowieckiego klasztoru ks. August Gauthier, dotychczasowego wikariusza prowincjalnego. W miarę przedłużania się wojny, nie tylko, że nie miał on możliwości niesienia bezpośredniej pomocy dla prowincji, lecz trapiły go ponadto obawy o jej losy - by hitlerowcy jej całkowicie nie zniszczyli. W razie gdyby do tego miało dojść, pragnął zabezpieczyć jej personalne odrodzenie poprzez powołania księży i braci polskiego pochodzenia na ternie Stanów Zjednoczonych i Kanady ${ }^{76}$. Jednak niektórzy współbraci mieli mu za złe, że opuścił kraj i prowincję polską. Byli nawet i tacy, którzy wprost oskarżali go o tchórzostwo i ucieczkę z posterunku. Czy mieli rację? Na to pytanie trudno jest dać pełną i kompetentną odpowiedź. Sam Bóg tylko wie po czyjej stronie była racja. Nam zaś pozostają suche fakty historyczne, które potwierdzaja, że dzieło w Olivet poprzez pomoc materialną przyczyniło się do odrodzenia polskiej prowincji. Ponadto dom zakonny we Lwowie, w którym mieszkał ks. Kolbuch jako prowincjał został zbombardowany przez Niemców w dniu 17 września 1939 r., a pod jego gruzami śmierć poniosło trzech saletynów: ks. dr Klemens Schleis (1900-1939),

${ }^{70} \mathrm{H}$. W r o ń s k a, Ojciec Michat Kolbuch niezmordowany apostoł Matki Bożej Placzącej z góry La Salette we Francji, Zielona Góra 1990, s. 15-27.

${ }^{71}$ P. J a m i o l, Saleryni..., s. 303-304.

72 Tamże, s. 298.

${ }^{73}$ Tamże, s. 304.

${ }^{74}$ ASD, Rada Prowincjalna - Okólniki, t. 1:1931-1951.

${ }^{75}$ AZSR, Kronika Alaî Francheville, s. 16; P. J a m i o ł, Saletyni..., s. 308.

${ }^{76}$ F. D a n i oł, Ks. Michat Kolbuch..., s. 15-16. 
ks. dr Ludwik Wołek (1900-1939) i ks. lic. Stanisław Zajchowski (1898-1939) oraz gospodyni i kilka osób, które schroniły się w jego piwnicach ${ }^{77}$. Niechaj każdy sam wyciagnie wnioski.

Ks. Michal Kolbuch początkowo zamieszkał w Ware (1939-1941) i szukal pomocy dla swojego dzieła. Po wielu trudach i inicjatywach uzyskał pomoc finansową od amerykańskich współbraci-saletynów oraz różnych ofiarodawców spośród ludzi świeckich. Początkowo ks. Kolbuch szukal miejsca na nowicjat w archidiecezji Chicago, w której przebywało najwięcej Polaków. Gdy nie uzyskał zgody ks. arcybiskupa z Chicago, wówczas zwrócil się o pomoc do bpa Schlarmana z diecezji Peoria w stanie Illinois. Ten przyjął projekt ks. Kolbucha $\mathrm{z}$ wielka radościa, a w dokumencie zezwalajacym na osiedlenie się w jego diecezji polskich saletynów napisał: Cieszę się, że w ten sposób choćby w małej części dopomogę bohaterskiej Polsce przyjmując do swojej diecezji Misjonarzy Matki Bożej z La Salette z Polski. Sam biskup poddał myśl zakupienia protestanckiego kolegium Nazarene w Olivet, Illinois ${ }^{78}$. W dniu 19 maja $1941 \mathrm{r}$. ks. prowincjał Michał Kolbuch zakupił za cenę 25 tysięcy dolarów protestanckie kolegium Nazarene w Olivet (USA) i tam założył Małe Seminarium, dom nowicjacki oraz zbudował kalwarię saletyńską z myślą aby przyjść z pomocą personalną polskiej prowincji. Po kilku latach saletyni miejsce w Olivet nazwali „Kalwarią saletyńską",79. W latach 19411942 był pierwszym przełożonym domu zakonnego w Olivet ${ }^{80}$. Małe Seminarium w Olivet dało z czasem początek nowej prowincji pod wezwaniem Matki Bożej Królowej Pokoju. To nowe dzieło ks. Kolbucha wydało w sumie ponad 40 księży i kilkunastu braci zakonnych.

Po zakończeniu działań wojennych, ks. Kolbuch natychmiast przystapił do organizowania pomocy materialnej dla polskiej prowincji, w postaci pieniędzy, odzieży i żywności. Oprócz tej działalności dla potrzeb swojego zgromadzenia postarał się u władz Stanów Zjednoczonych o pomoc materialną dla mieszkańców Polski za pomocą Caritas. Dzięki jego staraniom, tzw. Unra, czyli paczki żywnościowe docierały do wielu potrzebujących na terenie naszego kraju. Ponadto dla wielu ludzi dotkniętych kryzysem materialnym na skutek działań wojennych, postarał się o stałą pomoc materialną. Na podstawie źródeł archiwalnych należy podkreślić, że ks. Kolbuch dzięki swojej osobowości i charyzmatowi jaki otrzymał od Ducha Świętego potrafił odpowiedzieć na potrzeby ówczesnego człowieka. Przy pomocy organizacji międzynarodowych postarał się o pomoc dla Polaków, dotkniętych skutkami działań drugiej wojny światowej oraz repatriantów.

W roku 1946 kończyła się druga kadencja prowincjalstwa ks. Michała Kolbucha. Dlatego wikariusz zarządu generalnego, ks. Louis Sorrel, zwrócił się z prośbą do Kongregacji dla Spraw Zakonnych przy Stolicy Apostolskiej o to, by ks. Kolbuch nadal mógł pozostać na stanowisku przełożonego polskiej prowincji. Pozwolenie nadeszło w dniu 31 stycznia 1946 r., dzięki czemu został prowincjałem na trzecią 6-letnią kaden-

\footnotetext{
${ }^{77}$ P. J a m i o I, Saletyni..., s. 308-309.

${ }^{78}$ APSK. Księga uchwat rady prowincjalnej, t. 1: 1926-1966; P. J a m i o 1, Saletyni..., s. 316.

${ }^{79}$ F. D a n i o 1, Ks. Michat Kolbuch..., s. 15-16.

${ }^{80}$ AZSR, syg. G 10-IV, Ksiega uchwat rady generalnej, t. 5: 1933-1947.
} 
cję. W dniach 7-18 października 1946 r. ks. Kolbuch brał udział w obradach kapituły generalnej w Alaî Francheville (Francja) ${ }^{81}$ i na krótki czas odwiedził Polskę. W tym czasie dokonał krótkiej wizytacji polskiej prowincji i wystarał się o nową parafię Matki Bożej Saletyńskiej w Gdańsku-Sobieszewie ${ }^{82}$. Do kraju przybył na stałe dopiero na wrześniową uroczystość 100-lecia objawienia Matki Bożej w La Salette, która w Polsce - ze względu na zniszczenia wojenne - obchodzona była rok później niż we Francji, czyli w 1947 r. ${ }^{83}$ Tymczasem saletyni w Polsce po zakończeniu drugiej wojny światowej mieli pelne ręce pracy. Już w styczniu 1945 r. nawiązali kontakt z dawnymi uczniami i otworzyli Małe Seminarium w Dębowcu. W budynku klasztornym w Dębowcu po usunięciu zniszczeń powstałych wskutek działań wojennych, wraz z utworzonym komitetem złożonym z ludzi świeckich, a także w porozumieniu z władzami cywilnymi, otwarli też koedukacyjne Gimnazjum i Liceum „Oświata na Wsi”. Korzystali niego na równi z okoliczną młodzieżą męską i żeńską, również małoseminarzyści. Po zburzeniu przez nazistów Jasła, dębowiecka szkoła zastępowała leżące w gruzach Gimnazjum i Liceum jasielskie. Do utworzenia szkoły średniej w Dębowcu przyczynił się szczególnie ks. dr Józef Szczepański, późniejszy jej dyrektor oraz p. Józef Paluchniak z Dębowca, przewodniczący Komitetu Założycielskiego ${ }^{84}$. Natomiast o konieczne środki materialne dla funkcjon owania szkoły zabiegał w Ameryce ks. Kolbuch.

Ks. Michał Kolbuch swój czas pobytu w Polsce dobrzc wykorzystał, organizując odbudowę polskiej prowincji ze zniszczeń wojennych. $\mathrm{Z}$ jego inicjatywy odbudowano zburzone i uszkodzone domy zakonne oraz zorganizowano w nich pracę formacyjno-wychowawcza, podjęto pracę duszpasterską na Ziemiach Odzyskanych, szeroko otwarto się na pracę rekolekcyjno-misyjną. Z jego inicjatywy 15 sierpnia 1947 r. otwarto w domu zakonnym w Rzeszowie pierwszy powojenny nowicjat dla sześciu maturzystów. Pięciu z nich było wychowankami Małego Seminarium w Dębowcu oraz pierwszymi absolwentami dębowieckiej szkoły średniej ${ }^{85}$. Wszystkich więc - zarówno małoseminarzystów, nowicjuszów, jak i księży i braci zakonnych - ks. prowincjał Michał Kolbuch powitał z radością na polskiej ziemi w 1947 r. Dla każdego przygotował osobisty prezent. Najwięcej uwagi zwrócił na odbudowę zniszczonej redakcji „Posłańca", której uruchomienie miało doniosłe znaczenie dla organizującej się w warunkach powojennych pracy saletyńskiej w Polsce.

Prowincjał ks. Michał Kolbuch nie przebywał stale w Polsce, lecz często wracał do Ameryki, by zbierać fundusze na odbudowę polskich domów formacyjnych w Dębowcu i Rzeszowie. Jako prowincjał miał także zobowiązania również wobec Małego Seminarium, Nowicjatu i Wyższego Seminarium Duchownego w Olivet (USA) i dzieł w Argentynie, które mu podlegały pod względem zakonnym. W czasie pobytu w Polsce wystarał się u kard. Adama Stefana Sapiehy, metropolity krakowskiego, o kościół św. Norberta w Krakowie przy ul. Wiślnej wraz z budynkiem z przeznaczeniem na dom

\footnotetext{
${ }^{81}$ P. Jamiol, Saletyni..., s. 328.

${ }^{82}$ Tamże, s. 329.

${ }^{83}$ Tamże, s. 330.

${ }^{84}$ F. D a n i o 1, Ks. Michat Kolbuch..., s. 16; P. J a m i o ł, Saletyni..., s. 324.

${ }^{85}$ P. J a m i o 1, Saletyni..., s. 329.
} 
formacyjny dla kleryków saletyńskich, którzy to już od roku 1948 rozpoczęli formację intelektualną na Wydziale Teologicznym UJ w Krakowie. Postarał się również u prymasa Polski kard. Augusta Hlonda o przyjęcie saletynów do jego diecezji oraz o placówkę w Warszawie - Włochach Starych ${ }^{86}$.

W maju 1949 r., a więc w okresie stalinizmu, rozpoczęło się rozpracowywanie kurii krakowskiej przez funkcjonariuszy Urzędu Bezpieczeństwa. Pod spreparowanym zarzutem współpracy z obcym wywiadem aresztowano kilku kapłanów archidiecezji krakowskiej. Wśród podejrzanych był także prowincjał saletynów, ks. Michał Kolbuch, którego zaliczono do tzw. grupy szpiegowskiej. Działalność konspiracyjna ks. Kolbucha miała polegać na wysyłaniu informacji o sytuacji w kraju i odebraniu paczek z pieniędzmi i materiałami propagandowymi z USA. W czasie akcji likwidacji organizacji Caritas w Krakowie Wydział III WUBP w Krakowie zają się rozpracowywaniem wszystkich członków należących do Związku Caritas. Wówczas agenci UB odkryli działalność charytatywną ks. Kolbucha w okresie drugiej wojny światowej oraz w okresie powojennym, kiedy to przebywał w USA i organizował pomoc materialną na rzecz naszego kraju. Uznano go za zdrajcę i szpiega, a także podjęto decyzję o jego aresztowaniu. Jednak ks. Kolbuch został na czas ostrzeżony, iż jako obywatel amerykański jest poszukiwany i śledzony przez tajna policję. Dlatego pod koniec lipca 1949 roku opuścił Polskę i udał się do Stanów Zjednoczonych, tym razem definitywnie. Ostatnim miejscem pobytu ks. Kolbucha w Polsce był hotel Roma w Warszawie, w którym przebywał i przygotowywał się do wyjazdu za granicę. Warto podkreślić, że po opuszczeniu przez ks. Kolbucha pokoju hotelowego, już godzinę później pojawili się dwaj agencji UB w długich płaszczach aby go aresztować. Gdyby nie znajomości ks. Kolbucha, a także życzliwi mu ludzie, którzy mu pomagali, na pewno nie udałoby mu się uciec na $\operatorname{czas}^{87}$. Po wyjeździe ks. Kolbucha za granicę, w Polsce sprawował za niego urząd prowincjała jego dotychczasowy wikariusz, ks. August Gauthier.

\section{ASYSTENT GENERALNY}

Po przybyciu do Stanów Zjednoczonych ks. Kolbuch jeszcze z większym zapałem i z gorliwościa pracował dla dobra biednych i opuszczonych rodaków w Polsce, zbierając dla nich ofiary, ubranie i żywność. Na początku 1950 r. udał się do Rzymu z pielgrzymką na wielki jubileusz. Okazało się, że pielgrzymka przez niego organizowana powróciła bez niego do USA, a on pozostał w Rzymie ${ }^{88}$. W styczniu 1950 r. - po śmierci ks. Eliasza Roux w Rzymie w 1949 r. - został mianowany przez ks. generała Józefa Imhofa asystentem rady generalnej zgromadzenia. Przebywając odtąd w Rzymie, rozpoczął na wielką skalę działalność na rzecz byłych żołnierzy, ich rodzin oraz licznych uchodźców polskich na terenie całych Włoch, którzy nie chcieli wracać do kraju. Biskup Polowy Józef Gawlina, a zarazem ordynariusz Emigrantów Polskich

\footnotetext{
${ }^{86}$ AZSR, syg. G 10-IV, Ksiegga uchwat rady generalnej, t. 6: 1947-1952; P. Jamiol, Saletyni..., s. 334.

${ }^{87}$ AZSR, Fiche du personnel Michel Kobuch; Teczka personalna ks. Michała Kolbucha. 3, s. $85-86$.

${ }^{88}$ Zgon Ojca Michała Kolbucha Misjonarza Matki Boskiej Saletyńskiej, „PMBS-USA" R. 34:1958, nr
} 
w Europie, mianowal go za zgodą przełożonych zakonnym kapelanem Weteranów Polskich rozproszonych po całej Italii. Jako kapelan, ks. Kolbuch oddawał się całą dusza tym biednym i opuszczonym ludziom tak pod względem materialnym jak i moralnym ${ }^{89}$. Ileż odbył podróży, by dopomóc swym owieczkom! Ile napisał listów z prośbą o pomoc dla nich! Wydatkował się dla nich całkowicie. Jako kapelan kombatantów polskich objeżdżał ich ośrodki, przewodniczył ich zebraniom, odprawiał Msze św. na cmentarzach poległych polskich żołnierzy w Loreto, Monte Casino, Anconie, Bolonii i innych. Szczególnym staraniem i pieczołowitością otaczał polskie dzieci we Włoszech, a zwlaszcza sieroty. $Z$ ofiar nadesłanych mu przez przyjaciół sam nie korzystał, ale hojną ręką obdarzał tych maluczkich, którzy stracili ojców i matki w drugiej wojnie światowej. Starał się o mieszkania dla tych najbiedniejszych, urządzał szkółki, wysyłał na wakacje - to dla niego było najmilsze dzieło. Pisma i dzienniki rzymskie opisywały działalność pełną miłosierdzia, jaką otaczał tych najbiedniejszych w Wiecznym Mieście „Padre Michele".

W jego aktach znajduje się list kard. Eugène-Gabriel-Gervais-Laurent Tisserand, protektora zgromadzenia, do ks. generała Józefa Imhofa w sprawie pozwolenia dla ks. Kolbucha na wyjazd do Ameryki, aby tam zorganizował pomoc materialną dla ludności w Polsce, która po wojnie cierpiała na wiele niedostatków. Kard. Tisserand wyjaśniał, że napisał len list na prośbę pani Papée, żony ambasadora Polski przy Stolicy Apostol skiej, która była wówczas przewodnicząca Komitetu Pomocy Polakom. List nosił datę 23 maja $1952 \mathrm{r}^{90}$. Trzecia kadencja prowincjalstwa skończyła się dla ks. Kolbucha w 1952 r. Po nim na urząd prowincjała prowincji polskiej został mianowany 15 kwietnia 1952 r. przez ks. generała Imhofa i jego radę, ks. Bronisław Młynarski" ${ }^{91}$

Przez cały czas pobytu w Rzymie, oprócz posługi asystenta generalnego, ks. Kolbuch pełnił posługę misjonarza głosząc w USA, Kanadzie, Szwajcarii i we Włoszech misje i rekolekcje, a otrzymane ofiary przeznaczył na budowę domu generalnego i kościoła Matki Bożej z La Salette w Rzymie. W październiku 1955 r. na prośbę swych przełożonych, ks. Kolbuch ostatni raz udał się do Stanów Zjednoczonych w celu zbierania funduszy na budowę nowej świątyni parafialnej w Rzymie, pod wezwaniem Matki Bożej z La Salette. Odwiedził wówczas główne ośrodki polskie w Ameryce. Misja ta związana była z ogromnym trudem i wysiłkiem. Zaczynał pracę w parafiach w sobotę wysiadywaniem w konfesjonale przez długie godziny, a w niedzielę głosił homilie na wszystkich Mszach św. i osobiście zbierał ofiary. Wszystko to trwało ponad pół roku i było ponad jego siły ${ }^{y 2}$. Toteż do swej stałej siedziby na Monte Verde Nuovo w Rzymie wrócił sterany, chory, prawie niewidomy i częściowo sparaliżowany. Mimo, że pod koniec życia był ślepy i niepełnosprawnym, to jednak nadal pracował jako misjonarz i spowiednik w parafiach rzymskich ${ }^{93}$.

\footnotetext{
${ }^{89}$ AZSR, Notice necrologique..., s. 3.

${ }^{90}$ F. D a n i o 1, Ks. Michat Kolbuch..., s. 18

${ }^{91}$ P. J a m i o ł, Saletyni..., s. 342.

${ }^{92}$ F. D a n i o 1, Ks. Michal Kolbuch..., s. 18-19.

93 Tamże.
} 
Do samego końca swojego życia odprawiał Mszę św., którą zawsze celebrował z wielkim pietyzmem. Potwierdza to ks. Wilfryd Boulanger, asystent i sekretarz generalny, który jako ministrant był świadkiem ostatniej Mszy św. ks. Michała Kolbucha, pozostawiając świadectwo na piśmie. Tak pisze: „Podróż po Stanach Zjednoczonych zmieniła go do niepoznania. Do jego 68 wiosen życia przyłączyła się fatalna jesień, w czasie której stalowe zdrowie nagle zaczęło więdnać. Mimo zabiegów lekarzy amerykańskich paraliż mocno owładnął swą zdobycz. Osłabło tętno serca, nogi i ręce ciężyły ołowiem, a oczy zaledwie zdolne były odróżniać dzień od nocy. Księże Michale, trzeba będzie trochę odpocząć - zawyrokowałem, wzruszony niedołęstwem chorego, który mimo pomocy laski, z trudem trzymał się na nogach. Odpoczywać? - nie bierzcie mnie tak dramatycznie, odrzekł z energią sparaliżowany. To przejdzie. Czuję się wcale dobrze. Gdyby nie oczy, wcale bym się lekarzom nie naprzykrzał. Ważniejsza niż zdrowie jest sprawa budowy kościoła Matki Bożej z La Salette. To musi być coś naprawdę harmonizującego z pięknością świątyń rzymskich i miłością Polaków ku Matuchnie Niebieskiej. Chciałbym jeszcze być pożyteczny dla naszych weteranów w Italii i tutejszych sierót polskich. Szkoda, że tym razem tak mało dla nich w Ameryce nazbierałem. Ludzie tam zawsze są ofiarni, ale ja juź nie mogłem. Wargi chorego zaczęły drzeć, a powieki nie mogły łez zatrzymać. Podjęliśmy więc księdza Michała pod ramiona i prawie zanieśliśmy go do jego pokoju na drugim piętrze. Nikt z nas nie robił nadziei, żeby stosownie do marzeń kaleki powróciło jeszcze zdrowie w owe znieczulone członki. Wszelako wiedząc dobrze jak nieruchomość przygnębiała nigdzie nie osiadłego na stałe księdza Michała, baliśmy się o tym wspominać. Niestety, sam chory stopniowo przekonywał się o rzeczywistym stanie swojego zdrowia. Juź nazajutrz po przyjeździe do Wiecznego Miasta nie miał sił, by ubrać się i zejść do kaplicy. Umiejętność lekarza nie wiele pomocy mu dała. Niemożliwość wreszcie czytania i pisania przyczyniła się do tego, że bezwład organizmu przytłaczał najżywotniejsze ambicje zawsze czynnego umysłu. Tak stał się nierealny plan podróży do Argentyny, gdzie juź przez tyle lat nie widział założonych przez siebie placówek. Po kilku dniach taki sam los spotkał marzenie o wycieczce do Polski, na grób mamusi. Wreszcie z widnokręgu planów sparaliżowanego znikła pielgrzymka na La Salette, któremu zawdzięczał powołanie, natchnienia i zapał misjonarski.

Wśród kolejnej rezygnacji z robionych nie tak dawno planów, śmiała jednak myśl wywołała bunt i od razu urosła do rozmiarów niezmiennego postanowienia. Zawezwany więc do pokoju chorego usłyszałem formalny rozkaz: Jutro odprawiam Mszę św. Księże Michale, to jest niemożliwe - zaczałłem spokojnie dowodzić. Najpierw ksiądz nie może czytać. Po drugie, nie może rąk podnieść. Wreszcie, kto będzie księdza trzymał gdy nogi odmówią posłuszeństwa? «Na wszystko jest rada, - mówił mi z rozpromienionym czołem. Mszę o Matce Bożej umiem na pamięć, a Ojciec św. nie odmówi dyspensy, abym odprawił Mszę św. siedząco. Będzie to ostatnia łaska, o jaką bardzo proszę». Nie było wiele powodów ani czasu na jakiekolwiek perswazje. Chory na wszystkie zarzuty miał z góry obmyślane odpowiedzi. Stąd wnet udałem się do Rzymskiej Kongregacji w sprawie dyspensy, a po powrocie do domu nie wiedziałem czy mam się cieszyć że zdobytego przywileju czy raczej martwić się niespodziankami, jakie moga się zdarzyć sparaliżowanemu celebransowi przy ołtarzu. Rano ubraliśmy ka- 
lekę i ostroźnie sprowadziliśmy go po schodach do zakrystii. Po krótkiej modlitwie pomogliśmy przy wdziewaniu szat liturgicznych, po czym zaprowadziłem go do ołtarza. Tu ksiądz Michał usiadł na przygotowanym krześle, utkwił przygasłe oczy w wizerunku Ukrzyżowanego i zaczął drżącym głosem: «Przychodzę do ołtarza Bożego». «Do Boga, który rozwesela młodość moją» - odpowiedziałem bardziej wzruszony, niż w czasie moich prymicji. Słowo «przychodzę» wydawało mi się parodią, a niedołęstwo celebransa tak brało za serce, iż trzeba było silnych nerwów, by przemóc dławiąca emocję. Chory jednak wydawał mi się całkiem opanowany. Spokojnie odmawiał modlitwy Mszy św., recytował ustęp z księgi mądrości, powtarzał słowa improwizowane przez pobożną niewiastę, która w uwielbieniu Chrystusa zachwycała się dostojnością Jego Matki. Z kolei przyszło ofiarowanie. Ręce kapłana, co przez 40 lat codziennie podnosiły patenę $z$ hostia, dziś z trudem zaledwie oderwały się od kamiennej płyty ołtarza, podczas gdy usta szeptały: «Przyjmij Święty Ojcze, Wszechmogacy Boże tę hostię niepokalana...». Ten sam wysiłek powtórzył się przy ofiarowaniu kielicha. Słyszane następnie były prefacja i potrójne sanctus, wreszcie nastała zupełna cisza... Ksiądz Michał trwał ze złożonymi rękami, podobny do posągu. Nie zauważyłem ani oddechu ani ruchu powiek. Modlitwa zdawała mi się bardzo długa. Czyby może zemdlał? - zacząłem się niepokoić. Dla upewnienia się położyłem rękę na ramieniu celebrującego. Zareagował na moją uwagę lekkim skłonem głowy. Po tym uchwyciwszy się oburącz ołtarza podniósł się z krzesła. W końcu wziąl hostię w swe zdrętwiałe palce, skierowal oczy ku górze i naraz wybuchnał spazmatycznym płaczem... Zaskoczony niebywałym objawem wzruszenia, nie wiedziałem jak chorego uspokoić. Płacz zamienił się w nieutulone szlochanie dziecka. Podpowiadałem słowa konsekracji, starając się by dobrze były wymówione. Następnie podtrzymywałem kapłana z całej siły z obawy, by wskutek zapamiętania się, przy swoim kalectwie nie upadł na posadzkę. Wreszcie widząc jak jego niczym nie hamowane łzy spadają na ołtarz i na biała jak śnieg Hostię, byłem rozbrojony z resztek mojego zuchwalstwa i męskiej odporności. Od tej chwili ksiądz Michał nie miał już ministranta. Stałem bowiem przy ołtarzu jak płaczek na pogrzebie. Wiem jednak bardzo dobrze, że po konsekracji wszystkie modlitwy odmawiał głośno i płakał bez przerwy aż do Komunii św. przeciwnie, nie pamiętam czy w tym czasie przewracałem kartki w Mszale i czy w ogóle brałem udział w modlitwach. Zapanowałem nad sobą gdy celebrujący ponownie usiadł na krześle. Ofiara Mszy św. już była skończona. Ostatnia Ewangelia uspokoiła mnie całkowicie, a przy końcowych modlitwach nawet łzy obeschły. Wróciliśmy więc do zakrystii. Tu ksiądz Michał rzucił mi się na szyję. Był nad wyraz uszczęśliwiony. Dziękował mi za pomoc bardzo serdecznie, a usprawiedliwiając swe wzruszenie, dodał z rezygnacją: «Zdawało mi się, że była to ostatnia moja Msza św.». Nie długo czekałem na bolesną dla mnie wiadomość, że faktycznie byłem ostatnim ministrantem zmarłego księdza Michała Kolbucha"94.

Ks. Michał Kolbuch w Rzymie poddał się leczeniu, ale choroba czyniła postępy. Był to paraliź mózgu. W dniu 9 grudnia 1957 r. odwieziono go do kliniki Salvator Mundi w Rzymie. Pożegnał się ze wszystkimi współbraćmi, przepraszając ich za swoje grzechy i winy i dziękując za wszelka opiekę i pomoc. Gdy przybył do szpitala okazało

${ }^{94}$ Ostania Msza Śvięta, „PMBS-USA” R. 33:1958, nr 11, s. 306-309. 
się, że nie ma już dla niego ratunku. Agonia trwała 27 godzin. Przy łóżku obecni byli współbracia zakonni i kuzynka, która specjalnie przybyła z Polski. Po otrzymaniu ostatnich sakramentów św. oddał Panu Bogu ducha 13 grudnia 1957 r. o godz. $5^{35}$ w klinice Salvator Mundi w Rzymie ${ }^{95}$.

Uroczystości pogrzebowe odbyły się 15 grudnia 1957 r. w kościele Santa Maria del Monti, w pobliźu via Cavour. Biskup Józef Gawlina osobiście odprawił Mszę św. za „dobrego księdza Michała” w asyście duchowieństwa polskiego z Rzymu, aby w ten sposób wyrazić swe uznanie dla jego kapłańskiej i misjonarskiej posługi. Kościół był całkowicie wypełniony przez przyjaciół i znajomych zmarłego. Cała Polonia rzymska i okoliczna wzięła udział w tej ostatniej posłudze żałobnej, nie brakowało i tych najbiedniejszych, których wspierała dobroczynna ręka zmarłego. Bezpośrednio po Mszy św. i absolucji, ciało ks. Kolbucha zostało przetransportowane do Salmaty w pobliżu Nocera Umbria i złożone w grobowcu zgromadzenia, gdzie oczekuje na powszechne zmartwychwstanie. Ks. Michał Kolbuch należał do tych saletynów, którzy związek z Panem Bogiem, Matką Bożą z La Salette, zgromadzeniem i ojczystą kulturą potrafili wyrażać poprzez rzetelną pracę i czynną apostolską obecność w środowisku. Był on „światłem i solą ziemi” dla młodej polskiej prowincji ${ }^{96}$.

\section{PODSUMOWANIE}

W roku 2007, Zgromadzenie Misjonarzy Matki Bożej z La Salette obchodziło 50. rocznicę śmierci ks. Michała Kolbucha, stąd to przypomnienie jego osoby, życia i działalności. Można powiedzieć, że był to wielki człowiek, który dobrze wpisał się w historię zgromadzenia, w szczególności w historię polskiej prowincji i prowincji Matki Bożej Królowej Pokoju z Olivet (USA).

Cechowała go glęboka pobożność, miłość i przywiązanie do Matki Bożej z La Salette, która go urzekła i której wiernie służył. Miał wielką łatwość nawiązywania kontaktów z ludźmi i zdobywania współpracowników do realizacji licznych dziel, którym dał początek. Posiadał szerokie horyzonty i wielkie plany dotyczące podległej mu prowincji i zgromadzenia. Na szczególne wyróżnienie należy wymienić przede wszystkim jego optymizm, którego zewnętrznym wyrazem był uśmiech na twarzy. Był kapłanem i zakonnikiem dużej wiary. Nie załamywał się w trudnościach i doświadczeniach, których mu życie nie szczędziło.

Założone przez niego pisma saletyńskie w Polsce i w Ameryce, z wielkim skutkiem, roznosiły wiadomości o objawieniu Matki Bożej z La Salette i głosiły nauki wypływające $\mathrm{z}$ tego objawienia. Wielu saletynów, a także wiernych ma tak wiele mu do zawdzięczenia. Jego pamięć wciąż żyje w Polsce, w Stanach Zjednoczonych i w Rzymie.

Niech Dobry Bóg mu wynagrodzi za wszystko, co uczynił dla Kościola i zgromadzenia oraz narodu polskiego. Niech Maryja z La Salette, o której cześć tak zabiegał, przyłączy go w niebie do swych czcicieli. My - Saletyni - możemy odpłacić się mu swymi modlitwami jako współbratu, który wyprzedził nas do wieczności ze znamieniem wiary.

\footnotetext{
${ }^{95}$ AZSR, Notice necrologique..., s. 4; P. J a m i o 1, Saletyni..., s. 355-356.

${ }^{96}$ AZSR, syg. XIX-D-b1, J. I m h of, Notice necrologique... .
} 


\section{Résumé}

Le Révérend Père Michel Kolbuch, fịls de Jean Kolbuch et de Marie Kapijj naquit à BuskWolany en Galicie, Pologne, le 14 novembre 1889. Il fut baptisé dans l' église paroissiale de son village natal. C' est là aussi qu' il fit sa première Communion le 15 juin 1902, et qu' il reçu, l' an née suivante, le sacrament de Confirmation des mains se Son Excellence Mgr Bilczewski, Evêque de Lemberg. Un Missionnaire de Notre-Dame de la Salette, le P. Oswald Loretan, alors vicaire dans la paroisse de Busk, discerna dans le jeune Michel un germe de vocation sacerdotale et religieuse. Il le dirigea donc vers l' Ecole Apostolique de la Congrégation à Tournai en Belgique où il fut effectivement admis le 8 mai 1904. Il y apprit d' abord le fraçais et y fit ensuite ses etudes classiques de 1904 à 1911. Après un noviciat régulier à Suse, dans le Piémont en Italie, il y fit ses premiers voeux de religion le 8 septembre 1912 , et quatre ans plus tard, le 15 août 1916 dans la Chapelle de la Maison de campagne des Etudiants romains de notre Congrégation située dans le diocese de Nocera Umbra, il se consacra définitivement à Dieu et à Notre-Dame de la Salette par sa profession perpétuelle.

En l'été de 1913 il fut envoyé à Rome pour suivre, à l' Université Pontificale Grégorienne, les cours de philosophie et théologie. Orddonné Prêtrise le 2 décembre 1917 des mains de son Eminence le Cardinal Pompili, Vicaire de Sa Sainteté pour le diocese de Rome. Le Père Kolbuch êtait le premier prêtre polonaise de l' Institut des Missionnaires de Notre-Dame de la Salette.

Ses etudes terminées, fi fut nommé Sous-maître des Novices à Suse, ci-dessus mentionnée, où se trouvaient un certain nombre de Novices Polonais. Il remplit cette charge jusqu'à 1920. Il fut aloes envoi comme préfet de discipline à l'Ecole Apostolique à Dębowiec, en Pologne. II organisa notre Revue Salettine Polonaise à laquelle, par des efforts énergiques et constants, il trouva un nombre considerable d'abonnés. En 1923, le Père Kolbuch obtint de ses Supérieurs la permission de se render en Amérique pour y preacher des missions et des retraites et faire du ministère auprès des Polono-américains qui sont très nombreux aux Etats-Unis, et de les intéresser à nos Oeuvres en Pologne. Les fatigues que s' imposa le Père valurent toutes les resources qu' il trouva pour soutenir l' Ecole Apostolique et le Scolasticat de Pologne. Accumulant tâche sur tâche, le Père rédigea et publia aux Etats-Unis une revue Polonaise mensuelle qui, en peu de temps, atteignit un triage d' au delà de vingt mille exemplaires. En 1927, le Pére Kolbuch fut nommé Curé de la Paroisse Sainte Marie à Ware, dans l' Etat du Massachusetts, une des paroisses polonaises desservies par notre Congrégation aux Etats-Unis.

Lorsqu' en 1932 l' Institut fut divisé en Provinces canoniques, l' Administration Générale de la Congrégation nomma le R. P. Kolbuch le premier Supérieur Provincial de la Province NotreDame Reine de Pologne, charge qu' il occupera pendant trios sexennats, c' est-à-dire jusqu' à 1950 quand il fut élu Conseiller Général. Entre-temps, après un voyage en Amérique du Sud où il se rendit compte du nombre considerable et des necessities spirituelles des émigrés Polonais de ces vastes pays, le R. P. Kolbuch obtint des Supérieurs légitimes l' autorisation de fonder quatre Résidences en Argentine et d'y envoyer, à cet effet, des Pères et des Frères Coadjuteurs.

Ainsi que nous l' avons déjà dit ci-dessus, le R. P. Kolbuch fut appelé à la Curie Généralice dela Congrégation en 1950 pour remplacer le R. P. Elie Roux récemment décédé. Sans l'ombre d' un doute, cette obedience a dû lui être très pénible, car elle mettait fin, pour ainsi dire, aux exigences de son zèle insatiable. Mais bientôt, un nouveau champ d' apostolate s'ouvrit immense aux désirs ardents de son coeur missionnaire. Son Excellence Mgr. Joseph Gawlina, Archevêque Titulaire de Madito et Ordinaier des Emigré Polonais d' Europe, avec l' approbation des Supérieurs du R. P. Kolbuch, nomma celui-ci Chapelain des Vétérans Polonais éparpillés à travers toute l' Italie. En octobre 1955, le R. P. Kolbuch, sur les instances de ses Supérieurs, partit pour les EtatsUnis en vue d'y ramasser des fonds pour la construction de la nouvelle église paroissiale de Notre-Dame de la Salette à Rome. Il a parcouru la plupart des grands centres polonais d'Amérique, 
et chaque dimanche, après avoir, la veille, entendu des confessions pendant des heures interminables, il prêchait à toutes les mesmes et recueillait lui-même personnellement les offrandes que la charité des fidèles lui offrait.

Le 9 décembre, on le conduisit à la Clinique "Salvator Mundi" de Rome. C' est là, après un coma qui dura plus de 27 heures, que le malade, assisté deses Confrères et de sa Cousine germaine récemment artivée de Pologne, rendit son âme à Dieu le 13 décembre 1957. Les funérailles eurent le lendemain à l' Eglise Sainte Marie des Monts. Son Excellence Mgr. Joseph Gawlina tint à célébrer lui-même la Messe pontificale de Requiem afin de pouvoir donner au "bon Père Michel" une dernière marque de sa grande estime. L' Eglise fut remplie d' amis et de connaissances. Immédiatement aprèsla Messe et l' Absoute, la dépouille mortelle fut transportée à Salmata, près de Nocera Umbra, pour être deposée dans la caveau de la Congrégation, en entendant les joies d' une résurrection bienheureuse. 